\title{
Analysis of Typical Ozone Pollution Process in Jinan, Shandong province, China
}

\author{
Guiqin Zhang ${ }^{1, a}$, Chun Ding ${ }^{1, b}$, Huaizhong Yan ${ }^{2, c}$, Li Zhu ${ }^{1, d}$,Siyuan Li ${ }^{1, e}$
}

1. School of Municipal and Environmental Engineering, Shandong Jianzhu University, Jinan, Shandong Province, China

\section{Environmental Monitoring Center Station of Jinan, Shandong Province, China}

aemail, zhangguiqin320@163.com; bemail, 2379872861@qq.com; cemail, 1462731399@qq.com;

demail, 525932901@qq.com; eemail, 759286902@qq.com

Keywords: Ozone, Typical pollution process, spatial distribution, Source Analysis;

Abstract. Based on the monitoring data in the automatic ambient air monitoring station of Quancheng Square in Jinan from 0 o'clock of 11/06/2016 to 0 o'clock of 15/06/2016 as the typical pollution process, spatial distribution, related weather condition, ozone precursors, and regional transportation of ozone were analyzed. It showed that under the condition of high temperature, low humidity and southwest, the concentration of ozone was higher, and the daily changes of ozone pollution appeared single-peak and double-peak patterns. The relationship between Ozone Precursor and $\mathrm{O}_{3}$ was the negative correlation, and VOCs, especially aromatic hydrocarbon mainly control the concentration of $\mathrm{O}_{3}$. By analyzing the spatial distribution of $\mathrm{O}_{3}$ pollution and air mass trajectories on June 13th, it was found that the increase of the $\mathrm{O}_{3}$ concentration on the 12th night and the 13th early morning were closely related to the regional transport, and the pollution of $\mathrm{O}_{3}$ in the suburbs is more serious than that of downtown.

\section{Introduction}

Ozone $\left(\mathrm{O}_{3}\right)$ is one of the major atmospheric pollutants, and it is one of the substances that cause photochemical pollution in cities. Near-ground ozone can affect the growth of crops and plants, and harm human eyes, nasal mucosa and nervous system ${ }^{[1,2]}$. The concentration of $\mathrm{O}_{3}$ in the troposphere is mostly generated by local emissions of nitrogen oxides (NOx) and volatile organic compounds (VOCs) under sunlight. Once generated, $\mathrm{O}_{3}$ will exist in the troposphere for days or weeks and can affect the downwind region through long-distance air transmission ${ }^{[3]}$.

In recent years, in China, atmospheric oxidization has been increasing rapidly, and the $\mathrm{O}_{3}$ pollution in urban and rural has been exacerbated ${ }^{[4]}$. In China, ozone research has been carried out in many places. Wang found that the emissions of ozone precursor from urban areas are relatively high, the ratio of VOCs/NOX is relatively low, and $\mathrm{O}_{3}$ is controlled by VOCs. As the air mass moves, it gradually transitions to NOx controlled ${ }^{[5]}$. In rural areas, Biogenic emissions of VOCs are higher, $\mathrm{O}_{3}$ pollution is characterized as NOx control ${ }^{[6]}$. Besides, meteorological factors and regional transmission are also the form factor of ozone pollution.

At present, there is a lack of research on the characteristics of $\mathrm{O}_{3}$ pollution processes at home and abroad. The annual average 8-hour ozone concentration in Jinan during 2010-2016 ranged from 173 to $190 \mu \mathrm{g} / \mathrm{m}^{3}$, exceeding the national level II standard concentration $\left(160 \mu \mathrm{g} / \mathrm{m}^{3}\right)$. Ozone pollution was also severe from June 11 to June 14, 2016. This study discussed the pollution characteristics, meteorological conditions, and transport of regional air mass of the ozone pollution process from 0 o'clock of 11/06/2016 to 0 o'clock of 15/06/2016, which will contribute to providing the scientific basis to the prediction of $\mathrm{O}_{3}$ pollution control.

\section{Sample Collection and analysis}

Both the concentrations pollutants (such as $\mathrm{O}_{3}, \mathrm{NO}_{2}$, and $\mathrm{CO}$ ) and meteorological data (such as temperature, relative humidity, and wind direction) were from the automatic ambient air monitoring 
station called Quancheng Square station $\left(36.66^{\circ} \mathrm{N}, 117.02^{\circ} \mathrm{E}\right)$ from 0 o'clock of 11/06/2016 to 0 o'clock of 15/06/2016. The concentrations of VOCs were measured by on-line monitoring system. During the observation period, we use PAMS standard gas to calibrate, including 29 kinds of alkanes, 11 kinds of olefins and alkynes, and 16 kinds of aromatic hydrocarbons.

\section{Results and Discussion}

\section{Analysis of Typical Ozone Pollution Process}

The typical $\mathrm{O}_{3}$ pollution process was selected from 0 o'clock of 11/06/2016 to 15/06/2016 in Jinan, analyzing the changing process, including the concentration of pollutants (including $\mathrm{O}_{3}, \mathrm{NO}, \mathrm{NO}_{2}$, $\mathrm{CO}$, VOCs), temperature, relative humidity(RH). It can be seen from Fig. 1.

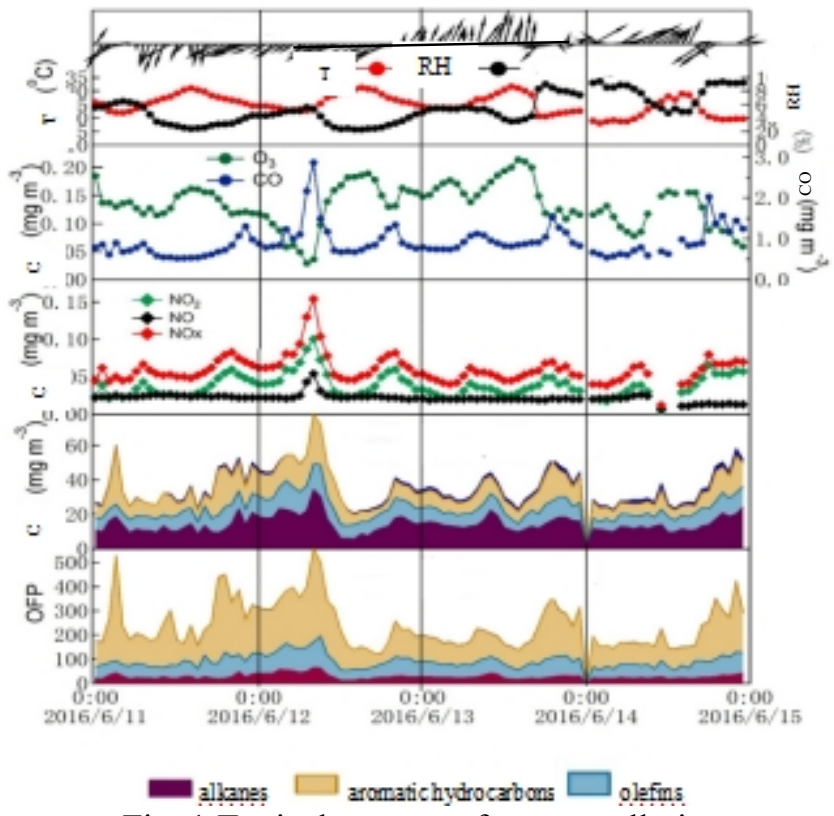

Fig. 1 Typical process of ozone pollution

\section{Ozone concentration changing process}

From 0 o'clock of 11/06/2016 to 15/06/2016, the maximum concentration of ozone for 8 hours was $175,177,178$, and $132 \mu \mathrm{g} / \mathrm{m}^{3}$ respectively, and ambient air quality reached slight pollution on the 11 th, 12th, and 13th. The concentrations of $\mathrm{O}_{3}$ showed a single-peak pattern on June 11th and 14th. The $\mathrm{O}_{3}$ concentration began to decline from 6 o' clock and reached the lowest value of the day at 7 o' clock. While solar radiation continued to increase, $\mathrm{O}_{3}$ continued to accumulate and reached a maximum at $13 \mathrm{o}^{\prime}$ clock and maintained to $17 \mathrm{o}^{\prime}$ clock, then it continued to decrease, reaching a low-value area during the day. The similar one-peak variations have also been confirmed in Spain and India ${ }^{[7,8]}$. There was a continuous high value of ozone concentration on the night of the 12 th and the early morning of the 13th, which may also be related to the transmission of ozone at night on the coastal areas.

\section{Relationship between ozone and ozone precursors}

As can be seen from the figure, there is a negative correlation between ozone concentration and ozone precursors. Ozone precursors (except $\mathrm{CO}$ ) accumulated from 0 o' clock to 6 o' clock, furthermore, the accumulation of VOCs was significantly higher than that of NOx, which showed that ozone is mainly controlled by VOCs. At the beginning of 6 o' clock, with the increase of traffic flow, NOx and VOCs began to increase, and the suppression of O3 by them strengthened. With the end of the morning peak, the suppression of $\mathrm{O}_{3}$ by their continuously weakened, and the series of photochemical reactions between them can also contribute to generating $\mathrm{O}_{3}$. With the increase of traffic flow from $17 \mathrm{o}^{\prime}$ clock, the titration effect of $\mathrm{NOx}$ and VOCs on $\mathrm{O}_{3}$ began to appear. At 6 o' clock-8 o' clock on the 12th, the concentration of VOCs, NOX, and CO increased sharply. This may be related to regional air masses transportation or local plentiful emissions. 
Ozone generation potential is an important index to measure the reactivity of ozone precursor and its effect on ozone generation. It's equation as follows:

$$
O F P_{i}=M I R_{i} \cdot\left[\operatorname{VOC}_{i}\right]
$$

In the equation, OFP is the ozone generation potential of the ozone precursor, MIR is the maximum incremental reactivity value of the ozone precursor, and [VOC] is its concentration in the ambient air.

The concentration and the ozone generation potential of VOCs was in the order of aromatic hydrocarbons $>$ olefins $>$ alkanes. It can be seen that the alkanes had a relatively high concentration and low reactivity, so their contribution to ozone is slight. The olefins had a higher reactivity due to its $\mathrm{C}=\mathrm{C}$ double bond and their contribution to ozone is higher than that of alkanes. Due to the highest concentration and reactivity, the contribution of aromatic hydrocarbons to ozone generation is the highest. So, the emission control of aromatic hydrocarbons from the petrochemical industry in Jinan should be highly focused on. On June 11th, the OFP peaked at 0 o'clock-6 o' clock in the early morning, and this is mainly due to the emission of VOCs at night and the lower height of the atmospheric boundary layer. OFP reached a high level from $18 \mathrm{o}$ ' clock on 11 th to $10 \mathrm{o}$ ' clock the next day, which may be related to atmospheric regional transportation.

\section{Relationship between ozone and meteorological conditions}

In view of weather conditions, there was a positive correlation between temperature and $\mathrm{O}_{3}$ concentration, and a negative correlation between relative humidity and $\mathrm{O}_{3}$ concentration. It can be seen that ozone is easily accumulated under high temperature and low humidity conditions ${ }^{[10]}$. From June 11th to June 12th, the wind direction of Jinan was dominated by northeast, and it changed to southwest or south from the 13th to the 14th, with a relatively high speed. The dominant wind direction in summer in Jinan is south, which is conducive to the transmission of regional pollutants. In view of the daily variation of $\mathrm{NO}_{\mathrm{x}}, \mathrm{CO}, \mathrm{VOCs}$, there was no significant concentration change except for the increase caused by traffic peaks in morning and evening. It can be seen that atmospheric diffusion conditions were not the main cause of $\mathrm{O}_{3}$ pollution in these days. However, the peak of these pollutants at the morning on the 12th was significantly higher than that on other days, and after 1-2 hours, the ozone concentration increased sharply, indicating there is accumulative effect of pollutants.

\section{Spatial Distribution of the Typical Pollution Process}

Using the Geographic Information System (ArcGIS), the spatial distribution of $\mathrm{O}_{3}$ pollution on June 13th in Jinan was further simulated, as shown in Fig. 2. It can be seen that the $\mathrm{O}_{3}$ pollution in different districts and counties was different. The $\mathrm{O}_{3}$ pollution was heavier in Shanghe County in the northeast, Pingyin County, and Changqing District in the southwest. The ozone concentration in the central part of Shanghe County reached $225-237 \mu \mathrm{g} / \mathrm{m}^{3}$, which is 1.4 times higher than the national level II standard. This may be due to the fact that the wind direction in Jinan on June 13th suddenly shifted from northeast to southwest. Shanghe County, located at downwind region, may have been affected by upwind pollution. However, the ozone pollution in the upwind Pingyin county is also heavy, which may be related to the emission of local pollution sources. Meanwhile, the $\mathrm{O}_{3}$ pollution in the downtown area is significantly lower than the urban suburbs, this may be due to the fact that with the high reactivity, the accumulated atmospheric pollutants in the urban area will temporarily decompose ozone into other substances, then they drifted to the suburbs with the wind and gradually reacted mutually to regenerate ozone. 


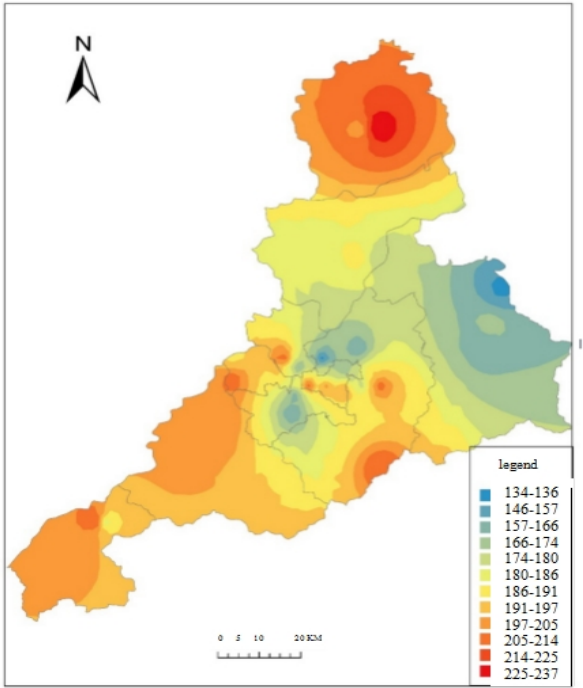

Fig. 2 Ozone spatial distributions on the typical ozone pollution process

\section{Source Analysis of the Typical Pollution Process}

Using the backward trajectory model HYSPLIT to analyze the sources of pollution air masses on June 13th, the meteorological data were collected from the National Oceanic and Atmospheric Administration of the United States (NOAA, http://ready.arl.noaa.gov/HYSPLIT.php), as shown in Fig.3. It can be seen that the polluting air mass on the different height of atmospheric boundary layer high came from the central and western part of Jiangsu Province. Firstly, it entered into the Anhui Province along the southwest direction, then circled there for a long time, and reached Jinan the next day along the northeast direction. It was detected by the ambient air ozone in Jiangsu Province and Anhui Province. From the on-line monitoring data of ozone in Jiangsu Province and Anhui Province, it can be seen that the ozone concentrations of Jiangsu Province and Anhui Province exceeded the national level II standard, showing that regional transportation is one of the causes of ozone pollution in Jinan on June 13th.

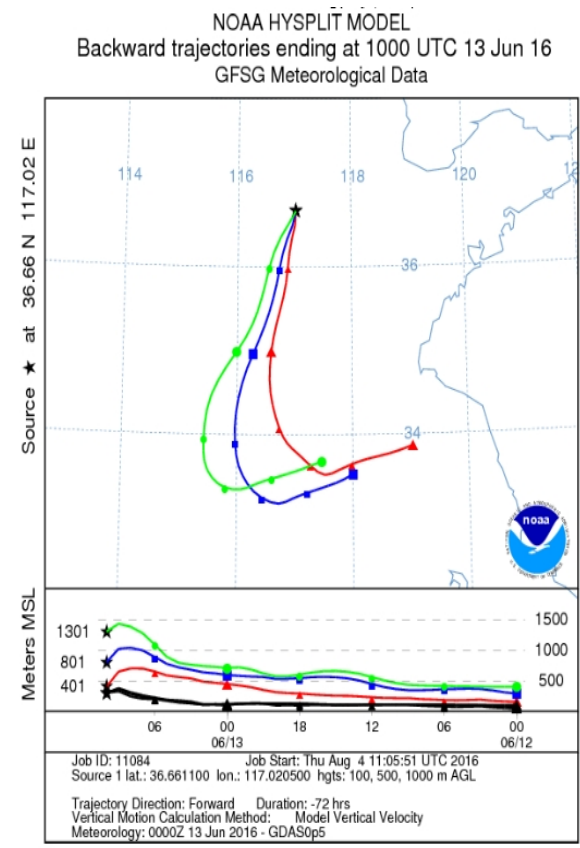

Fig. 3 backward trajectory analysis of 13/6/2016

\section{Conclusions}

By analyzing the typical $\mathrm{O}_{3}$ pollution process from 0 o'clock of $11 / 06 / 2016$ to $15 / 06 / 2016$, it was concluded that the daily $\mathrm{O}_{3}$ pollution changing process in Jinan showed the single-peak and double-peak pattern, reaching the maximum value of $178 \mu \mathrm{g} / \mathrm{m}^{3}$ in the maximum 8 -hour ozone 
concentration on the June $13^{\text {th }}$. The reason for this $\mathrm{O}_{3}$ pollution process may be related to the emission of $\mathrm{NO}_{\mathrm{X}}, \mathrm{CO}$, and VOCs; the order of ozone generation potential is aromatic hydrocarbons $>$ olefins $>$ alkanes; the weather condition with high temperature and low humidity, and regional air transport. The contaminated air masses entered into Jinan via the transmission channel from the central and western regions of Jiangsu Province. In addition, suburban ozone pollution was significantly stronger than that in center of the city, which may be related to the decomposition and secondary generation of ozone.

\section{Acknowledgments}

This work was financially supported by the Jinan Science and Technology Plan Project (No. 201302125).

\section{References}

[1] FRANCIS M, GROVES AM, SUN R, et al. CCR2 regulates inflammatory cell accumulation in the lung and tissue injury following ozone exposure [J]. Toxicol Sci, 155 (2): 474-484(2017).

[2] KHANIABADI YO, HOPKE PK, GOUDARZI G, et al. Cardiopulmonary mortality and COPD attributed to ambient ozone [J]. Environ Res, 152: 336-341(2017).

[3] VERSTAEFEN W W, NEU J L, WILLIAMS, J E et al. Rapid increases in tropospheric ozone production and export from China [J]. Nature Geoscience, 8: 690-695(2015).

[4] Cheng L J, Wang S, Gong Z Y, et al. Pollution trends of ozone and its characteristics of temporal and spatial distribution in Beijing-Tianjin-Hebei region [J]. Environmental Monitoring in China, 33 (1): 14 -21(2017).

[5] Wang T, Xue L, Brimblecombe P, Lam Y F, Li L, Zhang L. Ozone pollution in China: A review of concentrations, meteorological influences, chemical precursors, and effects. Sci Total Environ, 575:1582-1596(2017).

[6] Wei W, Lv Z, Cheng S, et al. Characterizing ozone pollution in a petrochemical industrial area in Beijing, China: a case study using a chemical reaction model [J]. Environmental Monitoring \& Assessment, 187(6):1-10(2015).

[7] DUENAS C, FERNÁNDEZ MC, CAÑETE S, et al. Assessment of ozone meteorological effects in an in the Mediterranean coast [J]. The Science of the Total Environment, 299: 97-113(2002).

[8] DEBAJE S B, JEYAKUMAR S J, GANESAN K, et al. Surface ozone measurements at tropical rural coastal station Tranquebar, India [J]. Atmospheric Environment, 37: 4911-4916(2003).

[9] CARTER WP L. Development of ozone reactivity scales for volatile organic compounds [J]. Journal of The Air \& Waste Management Association, 44 (7): 881-899(1994).

[10] NAIR P R, CHAND D, LAL S, et al. Temporal variations in surface ozone at Thumba $\left(8.6^{\circ} \mathrm{N}\right.$, $77^{\circ} \mathrm{E}$ ): a tropical coastal site in India [J]. Atmospheric Environment, 36: 603-610(2002). 